\title{
Morphology, Ontogeny and Molecular Phylogeny of a New Urostylid Ciliate, Bakuella (Pseudobakuella) Guangdongica n. sp. (Protista, Ciliophora, Hypotrichia) from Southern China
}

Jingyi Wang

Shaanxi Normal University

Jingbao Li

Northwestern Polytechnical University

Yurui Wang

Ocean University of China

Saleh A. Al-Farraj

King Saud University

Chen Shao ( $\square$ shaochen@snnu.edu.cn )

Shanxi Normal University https://orcid.org/0000-0001-8474-3204

\section{Research article}

Keywords: Morphology, Morphogenesis, New ciliate, Phylogeny, Soil

Posted Date: August 20th, 2020

DOI: https://doi.org/10.21203/rs.3.rs-55284/v1

License: (c) (1) This work is licensed under a Creative Commons Attribution 4.0 International License.

Read Full License 


\section{Abstract}

Background: Spirotrich ciliates are one of the most diverse groupsin the phylum Ciliophora and are widely distributed in marine, freshwater, and terrestrial biotopes. Many nominal species are, however, poorly known and their systematic positions remain uncertain due to the lack of information concerning their infraciliature, morphogenesis, and gene sequences. In this paper, the morphology and morphogenesis of Bakuella (Pseudobakuella) guangdongica $\mathrm{n}$. sp. were studied, in addition, genomic DNA was extracted in order to sequence the small subunit rDNA.

Results: Bakuella (Pseudobakuella) guangdongica n. sp. is characterized by $150-225 \mu \mathrm{m}$ in vivo; 35-42 adoral membranelles; three to five buccal, two frontoterminal and eight to 13 transverse + pretransverse cirri; midventral complex comprised of 10-20 midventral pairs and two midventral rows extending to transverse cirri; posterior part of marginal rows slightly overlapped; colorless cortical granules about $1 \mu \mathrm{m}$ across, arranged in small groups; soil habitat. Its main ontogenetic features are: (1) in the proter, the parental adoral zone of membranelles is completely renewed by new structures; (2) in the opisthe, the oral primordium originates apokinetally, some old midventral cirri join the formation of frontoventraltransverse cirral anlagen; (3) the anlagen for marginal rows and dorsal kineties develop intrakinetally; and (4) the numerous macronuclear nodules fuse into a single mass before dividing. Phylogenetic analyses based on the SSU rDNA sequence suggests the non-monophyly of the genus Bakuella.

Conclusions: The morphology, morphogenesis and molecular phylogeny of the new hypotrichous ciliate, Bakuella (Pseudobakuella) guangdongica n. sp. were studied, the phylogenetic analyses show that the Bakuella is polyphyletic in the SSU rDNA.

\section{Background}

The Hypotricha Stein, 1859 is a speciose and morphologically diverse group that inhabits a wide range of biotopes [1-11].

The genus Bakuella was erected by Agamaliev and Alekperov [12] with Bakuella marina Agamaliev \& Alekperov, 1976 as the type species. This genus is characterized by adoral zone of membranelles continuous, three enlarged frontal cirri, one or more buccal cirri, two or more frontoterminal cirri, midventral complex composed of obliquely arranged midventral pairs and midventral rows, one left and one right marginal cirral row, transverse cirri present and caudal cirri absent. So far, there are 13 species/subspecies that belong to this genus [1, 13-15]. Berger [1] divided Bakuella into two subgenera, Bakuella (Bakueklla) and B. (Pseudobakuella), mainly according to the number of frontoterminal cirri. The former has more than two frontoterminal cirri, while the latter has exactly two.

In March 23, 2016, a new soil urostylid ciliate was isolated from Guangdong, China. Observations of its morphology both in vivo and after protargol staining demonstrate that it represents a novel species within the genus Bakuella. In the present study, its morphology and morphogenesis were described. The small 
subunit ribosomal DNA (SSU rDNA) of the new isolate was sequenced and analysed in order to estimate its phylogenetic position.

\section{Results}

\section{Bakuella (Pseudobakuella) guangdongica n. sp. (Figs. 1A-F, 2A-L, 3A-I, 4A-H, Table 1)}


Table 1

Morphometric characterization of Bakuella (Pseudobakuella) guangdongica n. sp.

\begin{tabular}{|c|c|c|c|c|c|c|c|c|}
\hline Character $^{a}$ & HT & Min & Max & Mean & Med & SD & $\mathrm{CV}$ & $\mathrm{n}$ \\
\hline Body length & 195 & 170 & 240 & 209.3 & 210 & 17.6 & 8.4 & 23 \\
\hline Body width & 70 & 55 & 100 & 72.4 & 72 & 10.1 & 13.9 & 23 \\
\hline Body length: width, ratio & 2.79 & 2.20 & 4.27 & 2.93 & 2.86 & 0.41 & 13.83 & 23 \\
\hline AZM length & 70 & 62 & 80 & 69.2 & 70 & 4.2 & 6.1 & 23 \\
\hline AZM length: Body length, ratio & 0.36 & 0.26 & 0.38 & 0.33 & 0.33 & 0.03 & 7.58 & 23 \\
\hline Adoral membranelles, no. & 37 & 35 & 42 & 37.8 & 38 & 1.8 & 4.7 & 23 \\
\hline Frontal cirri, no. & 3 & 3 & 3 & 3.0 & 3 & 0 & 0 & 23 \\
\hline Buccal cirri, no. & 4 & 3 & 5 & 4.1 & 4 & 0.5 & 13.3 & 23 \\
\hline Frontoterminal cirri, no. & 2 & 2 & 2 & 2.0 & 2 & 0 & 0 & 23 \\
\hline Midventral pairs, no. & 16 & 10 & 20 & 15.4 & 16 & 2.8 & 17.9 & 23 \\
\hline Midventral rows, no. & 2 & 2 & 2 & 2.0 & 2 & 0 & 0 & 23 \\
\hline $\begin{array}{l}\text { The left midventral row, number of } \\
\text { cirri }\end{array}$ & 5 & 3 & 11 & 4.4 & 4 & 1.8 & 40.3 & 22 \\
\hline $\begin{array}{l}\text { The right midventral row, number of } \\
\text { cirri }\end{array}$ & 11 & 8 & 16 & 12.6 & 13 & 2.2 & 17.9 & 21 \\
\hline Right marginal cirri, no. & 54 & 37 & 59 & 46.9 & 47 & 5.6 & 11.9 & 23 \\
\hline Left marginal cirri, no. & 40 & 36 & 48 & 42.0 & 43 & 3.7 & 8.8 & 23 \\
\hline Transverse cirri ${ }^{b}$, no. & 9 & 8 & 13 & 10.7 & 10 & 1.3 & 12.4 & 23 \\
\hline Dorsal kineties, no. & 4 & 3 & 3 & 3.0 & 3 & 0 & 0 & 15 \\
\hline Dorsal kinety 1 , bristles, no. & 27 & 20 & 27 & 23.6 & 23 & 2.2 & 9.3 & 19 \\
\hline Dorsal kinety 2 , bristles, no. & 26 & 21 & 28 & 24.2 & 24 & 5.7 & 23.5 & 19 \\
\hline Dorsal kinety 3, bristles, no. & 25 & 23 & 29 & 26.5 & 27 & 1.9 & 7.2 & 17 \\
\hline Macronuclear nodules, no. & 225 & 110 & 230 & 159.2 & 146 & 36.6 & 23 & 21 \\
\hline Micronuclei, no. & 2 & 1 & 5 & 2.6 & 2 & 1.1 & 40.9 & 14 \\
\hline \multicolumn{9}{|c|}{$\begin{array}{l}\text { a All data are based on protargol-stained specimens, measurements in } \mu \text { m. Abbreviations: } A Z M \text {, } \\
\text { adoral zone of membranelles; } C V \text {, coefficient of variation in \%; HT, holotype; Med, median; Max, } \\
\text { maximum; Mean, arithmetic mean; Min, minimum; } n \text {, sample size; no., number; SD, standard } \\
\text { deviation. }\end{array}$} \\
\hline
\end{tabular}




\section{ZooBank registration}

Present work: urn:Isid:zoobank.org:pub:8BF9471D-94FF-41BA-9989-F21B93208429.

Bakuella (Pseudobakuella) guangdongica n. sp.:

urn:Isid:zoobank.org:act:825560C7-EFF0-4DF7-B895-848BED297FE3.

\section{Diagnosis:}

Body size 150-225 $\mu \mathrm{m} \times 40-75 \mu \mathrm{m}$ in vivo. Elongate with both ends rounded. 110-230 macronuclear nodules. Contractile vacuole positioned at about $35 \%$ of body length near left margin. Cortical granules spherical and colorless, $1 \mu \mathrm{m}$ in diameter, arranged in small groups. Adoral zone occupies about $33 \%$ of body length and composed of 35-42 membranes. Three frontal, three to five buccal, two frontoterminal and eight to 13 transverse cirri. Midventral complex composed of 10-20 pairs and two midventral rows comprising two to 11 and eight to 16 cirri, respectively. One left and one right marginal cirral rows, composed of 36-48 and 37-59 cirri, respectively. Three bipolar dorsal kineties.

\section{Type material:}

The protargol slide (registry no. WJY2016032301B) with the holotype specimen and one paratype slide (registry no. WJY2016032301C) were deposited in the Laboratory of Protozoological Biodiversity and Evolution in Wetland, Shaanxi Normal University, China.

\section{Type locality:}

Soil from Seaside Garden ( $\left.21^{\circ} 43^{\prime} 15^{\prime \prime} N ; 112^{\circ} 14^{\prime} 39^{\prime \prime} E\right)$, Yangjiang, Guangdong, China.

\section{Etymology:}

The species-group name "guangdongica" refers to the geographic location where the species was discovered.

\section{Morphology (Figs 1A-F, 2A-L, Table 1)}

Size 150-225 $\mu \mathrm{m} \times 40-75 \mu \mathrm{m}$ in vivo. Body elongate with both ends rounded and both margins almost straight; dorsoventrally flattened at a ratio of about 2:1, highly flexible but not contractile (Figs. 1A, 2A, B). 110-230 macronuclear nodules, oval to elongate in shape, scattered throughout cytoplasm, difficult to observe in vivo, one to five micronuclei (Table 1, Fig. 1F). Contractile vacuole about $16 \mu \mathrm{m}$ across when 
fully extended, positioned at about $35 \%$ of body length near left margin, pulsing at intervals of about $10 \mathrm{~s}$ (Figs. 1A, 2B). Pellicle thin and soft, with colorless spherical cortical granules, $1 \mu \mathrm{m}$ in diameter, arranged in small groups (Figs. 1B-D, 2C, D). Cytoplasm colorless to grayish, usually contains numerous lipid droplets (2-6 $\mu \mathrm{m}$ across) and food vacuoles (5-25 $\mu \mathrm{m}$ across) in middle portion that render cell opaque and dark in middle portion at low magnification (Fig. 2B, E). Locomotion by fast crawling over debris, sometimes rotating slowly around main body axis when swimming.

Consistently three relatively enlarged frontal cirri, with cilia $16 \mu \mathrm{m}$ long in vivo. Three to five buccal cirri arranged alongside paroral, cilia about $12 \mu \mathrm{m}$ in vivo. Two frontoterminal cirri slightly ahead of the level of cirrus III/2. Midventral complex composed of 10-20 pairs of cirri that extending to about two thirds of body length, together with two midventral rows comprising three to 11 (left one) and eight to 16 (right one) cirri respectively and both of which extending posteriad to transverse cirri. Eight to 13 transverse cirri with cilia ca. $20 \mu \mathrm{m}$ long in vivo. One left and one right marginal cirral rows, composed of 36-48 and 3759 cirri, respectively, cilia about $12 \mu \mathrm{m}$ long in vivo. Left marginal row commences left of proximal portion of adoral zone of membranelles (AZM) while right marginal row commences near anterior end on dorsal side, posterior ends of both terminate caudally and nearly confluent. Most somatic cirri relatively fine with cilia about $12 \mu \mathrm{m}$ long in vivo (Figs. 1E, F, 2H-K).

Three dorsal kineties extending almost entire length of cell, composed of 20-27, 21-28, and 23-29 dikinetids, respectively, with bristles about $5 \mu \mathrm{m}$ long in vivo (Figs. 1F, 2L).

Adoral zone occupies about $33 \%$ of body length after protargol impregnation, composed of 35-42 membranes, with cilia 18-20 $\mu \mathrm{m}$ long in vivo. Paroral strongly while endoral slightly curved and the former slightly shorter and lower than the latter.

\section{Morphogenesis during binary fission and physiological regeneration (Figs. 3A-I, 4A-H, 5A-R)}

\section{Stomatogenesis}

Stomatogenesis commences with the apokinetal formation of several groups of closely spaced basal bodies near the left cirri of midventral pairs, which is the oral primordium of the opisthe (Figs. 3A, B, 5A). No old structures join in the formation of the oral primordium. Then, these basal bodies increase in number and the oral primordium elongates to reach the level of the cytostome (Figs. 3A, B, 5B).

Subsequently, an anarchic field of closely arranged basal bodies originates de novo on the dorsal side of the buccal cavity. Meanwhile, the old undulating membranes begin to dedifferentitate (Figs. 3C, 5D, E). With the proliferation of more basal bodies, the oral primordium of the opisthe differentiates new membranelles posteriad and the oral primordium of the proter grows rapidly within a wedge-shaped, and the undulating membrane anlagen appear on the right of the oral primordia both in opisthe and proter (Fig. 3D, F). We failed to obtain specimens in early stage and were therefore unable to determine the 
origin of the undulating membrane anlagen both in opisthe and proter. The parental undulating membranes probably contribute to the formation of the undulating membranes anlage in proter. Meanwhile, the proximal portion of old AZM becomes disordered (Fig. 3D, F). Later, the new membranelles continue to differentiate in both the proter and opisthe, and the undulating membranes anlagen develop and give rise to the leftmost frontal cirrus in each the proter and opisthe (Figs. 3F, H, 4A, $5 \mathrm{G}, \mathrm{I})$. In late stages, the differentiation of membranelles is almost complete, forming the new structures for the proter and opisthe. Anterior ends of the new adoral bend to the right, and the undulating membranes anlagen split longitudinally into the endoral and paroral in each daughter cell. The parental AZM has been almost completely resorbed and the newly formed AZM eventually replaces the old one (Figs. 4A, C, E, 5L, N, P, Q).

\section{Development of the frontoventral-transverse cirri}

Development of the somatic ciliature begins with the formation of the frontoventral-transverse cirral anlagen (FVT-anlagen). In an early stage, the parental buccal cirri dedifferentiate, and possibly contribute to the formation of the proter's FVT-anlage (Fig. 3C). Later, several streaks are formed to the right of the oral primordium and develop into the FVT-anlagen. Some cirri of the midventral complex join in the construction of FVT-anlagen (Fig. 3D). Subsequently, with further basal bodies proliferation, two sets of FVT-anlagen are formed and become organized into about 20 oblique streaks posteriad (Figs. 3F, H, 5EG).

In middle to late stages, the FVT-anlagen for both daughters fragmentize and differentiate into new cirri (Figs. 3H, 4A, 5I). Later, the segregation of cirri from the FVT-anlagen is almost complete (Fig. 4A). Anlage II provides the second frontal cirrus and buccal cirri, anlage III produces the rightmost frontal cirrus and cirrus III/2, and midventral pairs develop from anlagen IV to n-2, two midventral rows formed from anlagen $n$ and $n-1$. The anterior portion of anlage $n$ forms two frontoterminal cirri additionally, while anlagen $n-12$ (or $n-11$ to $n-7$, deduced from morphometric data) to $n$ develop transverse cirri (Figs. 4C, $5 \mathrm{I}, \mathrm{L})$.

Finally, the cell begins to elongate, the daughters separate and new ciliary structures move further apart and migrate towards their final position. Two frontoterminal cirri migrate anteriorly and the parental structures are resorbed (Figs. 4E, 5N, P, Q).

\section{Development of marginal rows and dorsal kineties}

As is usual for most hypotrichs, marginal and dorsal kineties anlagen are formed intrakinetally both in the proter and the opisthe. These anlagen increase in size by further proliferation basal bodies and subsequently elongate and gradually replace the parental structures. Caudal cirri not formed (Figs. 3E, FI, 4A-F, 5H, J, L, O-Q). 


\section{Division of nuclear apparatus}

The nuclear apparatus divides in the usual way for urostylids, i.e. all macronuclear nodules fuse to form a single mass during the ontogenetic process and then divide into many nodules. Micronuclei were observed to divide mitotically during the morphogenesis (Figs. 3E, G, I, 4B, D, F, 5K, M, R).

\section{Physiological reorganisation (Fig 4G, H)}

Only one physiological regeneration stage was observed. From the data available, the main features of cortical development in reorganiser are similar to those in the proter, i.e.: (1) the parental undulating membranes are completely replaced by the new structure developing from undulating membranes anlage; (2) the undulating membranes anlage (= anlage I) gives rise to the leftmost frontal cirrus; (3) the number of frontoventral-transverse cirral anlagen about 20; and (4) the marginal rows and the dorsal kineties originate and develop in the same way as in cell division.

\section{Phylogenetic analyses based on SSU rDNA gene sequences (Fig. 6)}

The SSU rDNA sequence of Bakuella (Pseudobakuella) guangdongica n. sp. was deposited in GenBank with the accession number MT435536. The length and GC content of the new sequence are $1853 \mathrm{bp}$ and $44.47 \%$, respectively. Phylogenetic trees inferred from the SSU rDNA sequences, using two different methods ( $M L$ and $\mathrm{BI}$ ) show similar topologies; therefore, only the ML tree (Fig. 6) is presented with bootstraps and posterior probabilities from both algorithms.

Consistent with previous studies [16-19], the urostyloids are non-monophyletic in our phylogenetic tree. Bakuella (Pseudobakuella) guangdongica n. sp. is placed within the core urostylids and clusters together with Bakuella (Bakuella) granulifera, Neobakuella aenigmatica, Anteholosticha antecirrata and Urostyla grandis with full support. This group is sister to a clade formed by three Bakuella spp., two Diaxonella spp., Neobakuella flava and Apobakuella fusca (ML/BI, 97/1.00).

\section{Discussion}

\section{Morphological comparison with congeners}

According to Berger [1] and recent studies [13,15], there are 13 species included in the genus Bakuella, which consists of two subgenera discriminated by the number of frontoterminal cirri (more than two in Bakuella (Bakuella) vs. exactly two in Bakuella (Pseudobakuella). According to this definition, our form should be assigned to Bakuella (Pseudobakuella) and compared with three congeners, i.e. $B$. $(P$.) salinarum Mihailowitsch \& Wilbert 1990, $B(P$.$) walibonensis Song et al. 1992, and B$. (P.) litoralis Jo et al. 
2015. Bakuella nilgiri Kumar et al. 2010 was not designated in any subgenera in the original description [15]. Therefore, here we compare it to $B$. (P.) guangdongica n. sp.

Bakuella (Pseudobakuella) salinarum differs from $B$. (P.) guangdongica $\mathrm{n}$. sp. in having a larger body length in vivo (281-352 $\mu \mathrm{m}$ vs. $150-225 \mu \mathrm{m})$, more adoral membranelles (47-63 vs. 35-42), buccal cirri (six to eight vs. three to five), midventral pairs (22-38 vs. $10-20)$, and midventral rows (13-21 vs. two), as well as the habitat (salt water vs. soil) [1].

Bakuella (Pseudobakuella) litoralis can be separated from B. (P.) guangdongica n. sp. by brackish water (vs. soil) habitat, smaller body length in vivo (90-125 $\mu \mathrm{m}$ vs. $150-225 \mu \mathrm{m})$, the lower numbers of adoral membranelles (25-33 vs. 35-42), transverse and pretransverse ventral cirri (four to eight vs. eight to 13), and macronuclear nodules (49-84 vs. 110-230), posterior part of marginal rows clearly separated (vs. slightly overlapped), shorter length of midventral complex (extending to $70 \%$ of body length vs. near transverse cirri), and two types, yellowish or yellowish to colorless (vs. one type, colorless) cortical granules [14].

Bakuella (Pseudobakuella) walibonensis can be distinguished from $B$. (P.) guangdongica n. sp. by more buccal cirri (five or six vs. three to five) and midventral rows (two to five vs. two), fewer transverse cirri (four to six vs. eight to 13 ), the length of midventral complex extending to $54 \%$ of body length (vs. near transverse cirri) and salt water (vs. soil) habitat $[20,21]$.

Bakuella nilgiri differs from Bakuella (Pseudobakuella) guangdongica n. sp. in body length in protargol preparations (124-158 $\mu \mathrm{m}$ vs. $170-240 \mu \mathrm{m})$, the numbers of adoral membranelles (42-54 vs. 35-42), midventral rows (two to ten vs. two), frontoterminal cirri (two to four vs. invariable two), and dorsal bristles in total (88-135 vs. 64-84), as well as a larger adoral zone of membranelles relative to the body length (42-53\% vs. $26-38 \%)$ [15].

\section{Morphogenetic comparison with congeners}

The main characteristic events during morphogenesis in Bakuella (Pseudobakuella) guangdongica $\mathrm{n}$. sp. can be summarized as follows: (1) the parental adoral zone of membranelles is renewed completely; (2) FVT-anlagen are formed in secondary mode; (3) the oral primordium of the proter develops de novo on the dorsal side of the buccal cavity; (4) marginal row and dorsal kineties anlagen develop intrakinetally; and (5) macronuclear nodules fuse into a single mass before dividing.

Morphogenetic processes have been reported for five Bakuella species, namely, B. (Pseudobakuella) salinarum Mihailowitsch \& Wilbert, 1990, B. (Bakuella) edaphoni Song et al., 1992, B. (Bakuella) pampinaria Eigner \& Foissner, 1992, B. nilgiri Kumar et al., 2010 and B. (Bakuella) subtropica Chen et al., 2013 [1, 13, 15, 20-22]. In general, Bakuella (Pseudobakuella) guangdongica n. sp. resemble its congeners morphogenetically in the following aspects: (1) old cirri join the formation of the FVT-anlagen; (2) new marginal rows and dorsal kineties develop within parental structures; and (3) the numerous 
macronuclear nodules fuse into a single mass, however, some differences among them exist, which have been commented in detail by Chen et al. [13].

\section{Phylogenetic analyses}

The SSU rDNA gene sequences of four Bakuella species are available from GenBank, namely, $B$. (Bakuella) granulifera, B. (Bakuella) subtropica, B. (Pseudobakuella) litoralis and B. (Bakuella) incheonensis. These four species, along with the new species show a nonmonophyletic relationship. In the SSU rDNA tree, B. (Pseudobakuella) guangdongica n. sp. and B. (B.) granulifera cluster with Neobakuella aenigmatica, Anteholosticha antecirrata and Urostyla grandis. The close relationship between these five species is supported by several morphological features including: caudal cirri absent, transverse cirri and cortical granules present. The remaining Bakuella species, i.e., $B$. (B.) subtropica, $B$. (B.) incheonensis and $B$. (P.) litoralis nested in a clade with Diaxonella species, Neobakuella flava and Apobakuella fusca. The results of our molecular phylogenetic analyses are consistent with those of previous molecular studies $[14,18]$.

The ambiguous relationship of these five Bakuella species might be due to the limited sampling of representative taxa in the SSU rDNA tree. Therefore, SSU rDNA sequences from more taxa, especially the type species Bakuella marina, and sequence data for additional gene markers, are needed in order to enhance our understanding of the molecular phylogeny of Bakuella.

\section{Conclusions}

In this manuscript, the new soil species, Bakuella (Pseudobakuella) guangdongica n. sp. collected from the Seaside Garden, expand the knowledge of biodiversity of ciliates. Moreover, the molecular data of the species is provided for the first time and the phylogenetic relationships among related genera and species are discussed.

\section{Methods}

\section{Sampling and cultivation}

Samples were collected from the upper soil layer of Seaside Garden, Yangjiang, Guangdong, China $\left(21^{\circ} 43^{\prime} 25^{\prime \prime} \mathrm{N} ; 112^{\circ} 14^{\prime} 55^{\prime \prime} \mathrm{E}\right)$ on March 23,2016 . We do not need any permission to collect the samples. Ciliates were made to excyst by employing the non-flooded Petri dish method as described by Foissner [23]. A non-clonal culture was established at room temperature (about $24^{\circ} \mathrm{C}$ ) in Petri dishes containing mineral water (Nongfu Spring) with rice grains to enrich the bacterial food. The probability is therefore extremely high that our morphological, morphogenetic and molecular studies deal with the same species although we were unable to establish clonal cultures, because we were able to identify the species accurately based on its in vivo morphologic characteristics. 


\section{Morphology and morphogenesis}

Cells were observed in vivo using bright field and differential interference contrast microscopy. The protargol staining [24] was used to reveal the ciliature and nuclear apparatus, protargol was made according to Pan et al. [25]. Counts and measurements of stained specimens were performed at a magnification of $1,000 \times$. Drawings of protargol-prepared cells were made with the help of a camera lucida. To illustrate the changes occurring during morphogenetic processes, old (parental) ciliary structures are depicted by contour whereas new structures are shaded black. Terminology and Systematics are mainly according to Berger [1].

\section{DNA extraction, PCR amplification, and sequencing}

One cell of Bakuella (Pseudobakuella) guangdongica n. sp. was isolated and repeatedly washed using sterile distilled water. Then it was transferred to a $1.5-\mathrm{ml}$ microfuge tube with a minimum volume of water. Genomic DNA was extracted from cells using DNeasy Blood \& Tissue Kit (Qiagen, CA) following the manufacturer's instructions. PCR amplification and sequencing of the SSU rDNA were performed according to Wang et al., [26] using the eukaryotic universal SSU rDNA primers 18S-F (5'-AAC CTG GTT GAT CCT GCC AGT-3') and 18S-R (5'-TGA TCC TTC TGC AGG TTC ACC TAC-3') [27]. High-fidelity Taq polymerase (Takara Ex Taq; Takara Biomedicals) was used to minimize the possibility of amplification errors. Polymerase chain reaction conditions for the SSU rDNA amplification were as follows: 2 min initial denaturation $\left(98^{\circ} \mathrm{C}\right.$ ) followed by 30 cycles of denaturation for $10 \mathrm{~s}$ at $98^{\circ} \mathrm{C}$, annealing for $15 \mathrm{~s}$ at $56^{\circ} \mathrm{C}$, and extension for $1 \mathrm{~min} 50 \mathrm{~s}$ at $72{ }^{\circ} \mathrm{C}$, with a final extension of $7 \mathrm{~min}$ at $72^{\circ} \mathrm{C}$. Sequencing of the PCR products was performed bidirectionally on an ABI 3700 sequencer (Invitrogen sequencing facility, Shanghai, China).

\section{Phylogenetic analyses}

In order to perform phylogenetic analyses, the SSU rDNA of Bakuella (Pseudobakuella) guangdongica n. sp. was aligned with sequences of 63 other hypotrichs downloaded from GenBank database (for accession numbers, see Fig. 6). Four euplotid species, namely Apodiophrys ovalis, Diophrys scutum, Paradiophrys zhangi, and Uronychia multicirrus, were used as outgroup taxa. All sequences were aligned using the GUIDANCE web server (http://guidance.tau.ac.il/, [28]). Both ends of the alignments were trimmed and ambiguous columns were removed based on confidence scores calculated by GUIDANCE. Maximum likelihood (ML) analyses were performed using RAXML-HPC2 on XSEDE v8.1.11 $[29,30]$ on the online server CIPRES Science Gateway [31]. The reliability of internal branches was assessed using a nonparametric bootstrap method with 1,000 replicates. Bayesian inference (BI) analyses were carried out using MrBayes on XSEDE v3.2.6 [32] on CIPRES Science Gateway with the GTR $+1+G$ model selected by Akaike Information Criterion (AIC) in MrModeltest v2 [33]. Markov chain Monte Carlo simulations were run with two sets of four chains for 2, 000, 000 generations with a sample frequency of 100 generations and 
discarding the first 5,000 trees as a burn-in (25\%). All remaining trees were used to calculate posterior probabilities using a 50\% majority rule consensus. TreeView v1.6.6 and MEGA v5 were used to visualize the tree topologies $[34,35]$.

\section{Abbreviations}

AZM: adoral zone of membranelles; BI: Bayesian inference; bp: base pairs; DK: dorsal kinety; FVT:

frontoventral-transverse cirrl; GC: Guanine-cytosine; GTR + I + G: General time reversible + invariable sites + gamma model of nucleotide substitution; ML: Maximum likelihood; $n$. sp.: nova species; PCR: Polymerase chain reaction; spp.: species (plural); SSU rDNA: Small subunit ribosomal DNA.

\section{Declarations}

Ethics approval and consent to participate

Not applicable.

Consent for publication

Not applicable.

Availability of data and materials

Sequence data are available in GenBank (Accession Number: MT435536).

The datasets used and/or analyzed during the current study are available from the corresponding author on reasonable request. One permanent slide containing the protargol-impregnated holotype specimen of Bakuella (Pseudobakuella) guangdongica n. sp. (registry no. WJY2016032301B) and one paratype slide (registry no. WJY2016032301C) were deposited in the Laboratory of Protozoological Biodiversity and Evolution in Wetland, Shaanxi Normal University, China.

Competing interests

The authors declare that they have no competing interests.

Funding

This work was supported by the Natural Science Foundation of China (Project number: 31872190), and the Researchers Supporting Project (RSP-2020/7) of the King Saud University, Saudi Arabia. The funding body had no role in study design, data collection, analysis and interpretation, and in writing of the manuscript.

Authors' contributions 
JW collected the samples and carried out almost of the experiments (preparations, illustrations, micrographs, etc.). JL finished the calculations, sequencing. YW performed phylogenetic analyses. SAA was responsible for the language correction. CS did the identification of the species, taxonomic analysis and revision of the manuscript. All authors prepared the manuscript and approved the final version.

\section{Acknowledgements}

The authors would like to thank anonymous reviewers for their thoughtful critiques that helped improve the manuscript.

\section{References}

1. Berger H. Monograph of the urostyloidea (Ciliophora, Hypotricha). Monogr Biol. 2006;85:1-1304.

2. Berger H. Monograph of the Amphisiellidae and Trachelostylidae (Ciliophora, Hypotricha). Monogr Biol. 2008;88:1-

3. Bhartia D, Kumar S, Terza AL, Chandra K. Morphology and ontogeny of Tetmemena pustulata indica subspec. (Ciliophora, Hypotricha), from the Thane Creek, Mumbai, India. Eur J Protistol. 2019;71:125629.

4. Dong J, Li L, Fan X, Ma H, Warren, A. Two Urosoma species (Ciliophora, Hypotrichia): A multidisciplinary approach provides new insights into their ultrastructure and systematics. Eur $\mathrm{J}$ Protistol. 2020;72:125661.

5. Hu X, Lin X, Song W. Ciliates Atlas: Species Found in the South China Sea. Science Press, Beijing. 2019.

6. Jung JH, Berger H. Monographic treatment of Paraholosticha muscicola (Ciliophora, Keronopsidae), including morphological and molecular biological characterization of a brackish water population from Korea. Eur J Protistol. 2019;68:48-

7. Luo X, Huang J, Li L, Song W, Bourland WA. Phylogeny of the ciliate family Psilotrichidae (Protista, Ciliophora), a curious and poorly-known taxon, with notes on two algae-bearing psilotrichids from Guam, USA. BMC Evolut Biol. 2019;19:125.

8. Park KM, Jung JH, Jeong HK, Min GS, Kim S. Morphology, morphogenesis, and molecular phylogeny of a new freshwater ciliate, Gonostomum jangbogoensis sp. (Ciliophora, Hypotricha), from Victoria Land, Antarctica. Eur J Protistol. 2020;73:125669.

9. Shao C, Hu C, Fan Y, Warren A, Lin X. Morphology, morphogenesis and molecular phylogeny of a freshwater ciliate, Monomicrocaryon euglenivorum euglenivorum (Ciliophora, Oxytrichidae). Eur $\mathrm{J}$ Protistol. 2019;68:25-36.

10. Song W, Shao C. Ontogenetic Patterns of Hypotrichs Ciliates. Science Press (in Chinese). 2017;12:1497.

11. Zhang T, Dong J, Cheng T, Duan L, Shao C. Reconsideration of the taxonomy of the marine ciliate Neobakuella aenigmatica Moon et al., 2019 (Protozoa, Ciliophora, Hypotrichia). Mar Life Sci Technol. 
2020; 2:97-

12. Agamaliev FG, Alekperov IK. A new genus Bakuella (Hypotrichida) from the Caspian Sea and the Djeiranbatansky water reservoir. Zool Zh. 1976;55:128-131.

13. Chen X, Hu X, Lin X, Al-Rasheid KAS, Ma H, Miao M. Morphology, ontogeny and molecular phylogeny of a new brackish water ciliate Bakuella subtropica n. (Ciliophora, Hypotricha) from southern China. Eur J Protistol. 2013;49:611-622.

14. Jo E, Jung JH, Min GS. Morphology and Molecular Phylogeny of Two New Brackish Water Ciliates of Bakuella (Ciliophora: Urostylida: Bakuellidae) from South Korea. J Eukaryot Microbiol. 2015;62:799-

15. Kumar S, Kamar K, Sapra G. Ciliates of the Silent Valley National Park, India: Urostyloid Hypotrichs of the region with a note on the Habitat. Acta Protozool. 2010;49:339-

16. Chen L, Dong J, Wu W, Xin Y, Warren A, Ning Y, et al. Morphology and molecular phylogeny of a new hypotrich ciliate, Anteholosticha songi spec., and an American population of Holosticha pullaster (Müller, 1773) Foissner et al., 1991 (Ciliophora, Hypotrichia). Eur J Protistol. 2020;72:125646.

17. Jung JH, Omar A, Kim KS, Kang SC, Kwak DY, Sun JH, Min GS. A study on the non-monophyletic genera Australothrix and Holostichides based on multigene and morphological analyses with a reexamination of type materials (Protozoa: Ciliophora). Mol Phylogenet Evol. 2019;139:106538.

18. Lyu Z, Wang J, Huang J, Warren A, Shao C. Multigene-based phylogeny of Urostylida (Ciliophora, Hypotrichia), with establishment of a novel family. Zool Scr. 2018;47:243-254.

19. Zhang T, Qi H, Zhang T, Sheng Y, Warren A, Shao C. Morphology, morphogenesis and molecular phylogeny of a new brackish water subspecies, Neourostylopsis flava paraflava subsp. (Ciliophora, Hypotrichia, Urostylidae), with redefinition of the genus Neourostylopsis. Eur J Protistol. 2018;66:4862.

20. Mihailowitsch B, Wilbert N. Bakuella salinarum spec.und Pseudokeronopsis ignea nov. spec. (Ciliata, Hypotrichida) aus einem solebelasteten Fliessgewässer des östlichen Münster-landes. BRD. Arch Protistenkd. 1990;138:207-219.

21. Song, W., Wilbert, N., and Berger. H. Morphology and morphogenesis of the soil ciliate Bakuella edaphoni spec. and revision of the genus Bakuella Agamaliev \& Alekperov, 1976 (Ciliophora, Hypotrichida). Bull Br Mus Nat Hist. (Zool.) 1992;58:133-148.

22. Eigner $\mathrm{P}$, Foissner W. Divisional morphogenesis in Bakuella pampinaria spec. and reevaluation of the classification of the urostylids (Ciliophora, Hypotrichida). Europ J Protistol. 1992;28:460-470.

23. Foissner W. Soil protozoa: fundamental problems, ecological significance, adaptations in ciliates and testaceans, bioindicators, and guide to the literature. Progr Protistol. 1987;2:69-212.

24. Wilbert N. Eine verbesserte technik der Protargolimprägnation für ciliaten. 1975;64:171-179.

25. Pan X, Bourland W, Song W. Protargol synthesis: an in-house protocol. J Eukaryot Microbiol. 2013;60:609-614.

26. Wang J, Zhao Y, Lu X, Lyu Z, Warren A, Shao C. Does the Gonostomum-patterned oral apparatus in hypotrichia carry a phylogenetic signal? Evidence from morphological and molecular data based on 
extended taxon sampling using three nuclear genes (Ciliophora, Spirotrichea). Sci China Life Sci. 2020;63, https://doi.org/10.1007/s11427-020-1667-3.

27. Medlin L, Elwood HJ, Stickel S, Sogin ML. The characterization of enzymatically amplified eukaryotic 16S-like rRNA-coding regions. 1988;71:491-499.

28. Penn O, Privman E, Ashkenazy H, Landan G, Graur D, Pupko T. GUIDANCE: a web server for assessing alignment confidence scores. Nucleic Acids Res. 2010;38:W23-W28.

29. Stamatakis A. RAXML version 8: a tool for phylogenetic analysis and post-analysis of large phylogenies. Bioinformatics. 2014;30:1312-1313.

30. Stamatakis A, Hoover P, Rougemont J. A rapid bootstrap algorithm for the RAxML web-servers. Syst Biol. 2008;57:758-771.

31. Miller MA, Pfeiffer W, Schwartz T. Creating the CIPRES science gateway for inference of large phylogenetic trees. In: Proceedings of the Gateway Computing Environments Workshop (GCE), New Orleans, LA. 2010.

32. Ronquist F, Teslenko M, van der Mark P, Ayres DL, Darling A, Höhna S, et al. MrBayes 3.2: efficient Bayesian phylogenetic inference and model choice across a large model space. Syst Biol. 2012;61:539-542.

33. Nylander JAA. MrModeltest, Version 2.2. Program distributed by the author. Evolutionary Biology Centre, Uppsala University, 2004.

34. Page RDM. TreeView: an application to display phyloge-netic trees on personal computers. Comput. Appl Biosci. 1966;12:357-358.

35. Tamura K, Peterson D, Peterson N, Stecher G, Nei M, Kumar S. MEGA5: molecular evolutionary genetics analysis using maximum likelihood, evolutionary distance, and maximum parsimony methods. Mol Biol Evol. 2011;28:2731-2739.

\section{Figures}




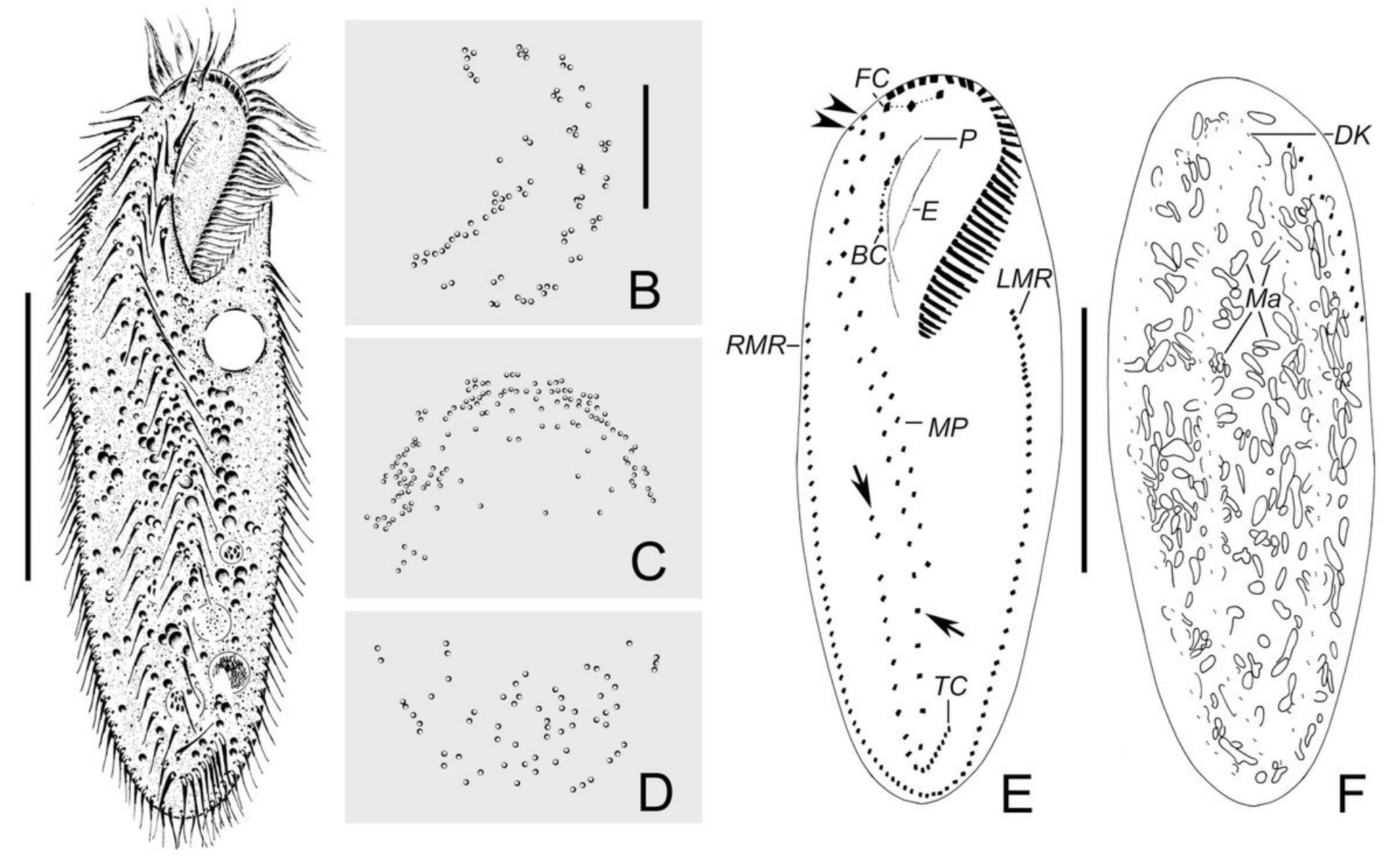

Figure 1

A-F. Morphology and infraciliature of Bakuella (Pseudobakuella) guangdongica $n$. sp. from life (A-D) and after protargol staining $(E, F)$. (A) Ventral view of a representative individual. (B-D) Ventral view (B), as well as anterior (C) and posterior (D) part in dorsal view, to show arrangement of cortical granules. (E, F) Ventral $(E)$ and dorsal $(F)$ view of a same specimen, showing the infraciliature and nuclear apparatus, arrowheads mark frontoterminal cirri and arrows show the midventral rows. BC, buccal cirri; DK, dorsal kineties; $E$, endoral; $F C$, frontal cirri; $L M R$, left marginal row; Ma, macronuclear nodules; MP, midventral pairs; P, paroral; RMR, right marginal row; TC, transverse cirri. Scale bars = $70 \mu \mathrm{m}(A, E, F) ; 30 \mu \mathrm{m}$ (B-D). 

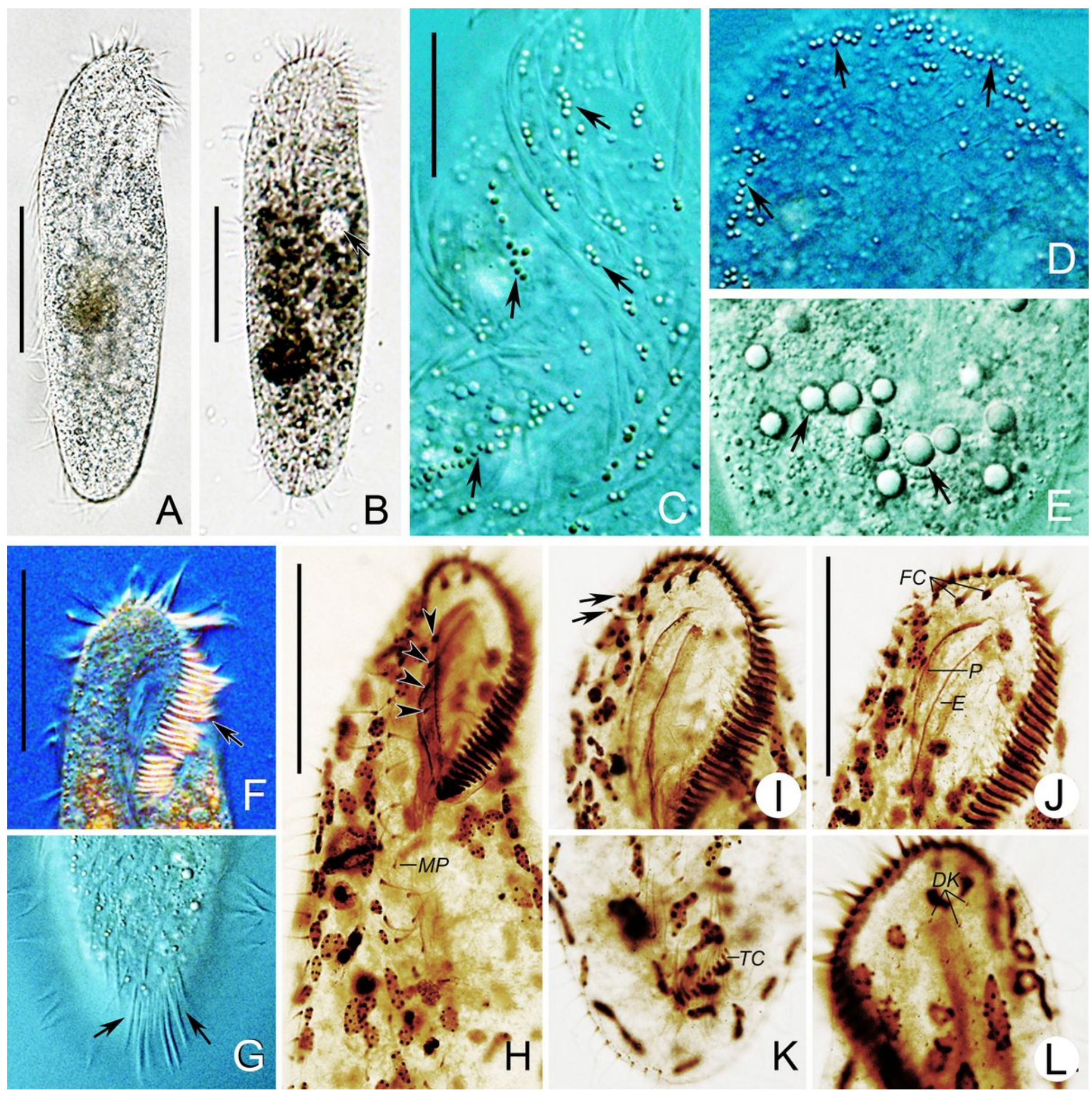

Figure 2

A-L. Photomicrographs of Bakuella (Pseudobakuella) guangdongica n. sp. from life (A-G) and after protargol impregnation $(\mathrm{H}-\mathrm{L})$. (A, B) Ventral views of representative individuals, arrow indicates contractile vacuole. (C, D) Ventral (C) and dorsal (D) views, to denote the arrangement of cortical granules (arrows). (E) Lipid droplets (arrows). (F) Ventral view, to mark the adoral zone of membranelles (arrow). (G) Ventral view of posterior portion, to depict transverse cirri (arrows). (H-K) Ventral views to show ventral ciliature, arrows mark the frontoterminal cirri and arrowheads point to the buccal cirri. (L) Dorsal 
view, to show the dorsal kineties. DK, dorsal kineties; E, endoral; FC, frontal cirri; MP, midventral pairs; $\mathrm{P}$, paroral; TC, transverse cirri; Scale bars $=60 \mu \mathrm{m}(\mathrm{A}, \mathrm{B}, \mathrm{F}, \mathrm{H}, \mathrm{J}) ; 15 \mu \mathrm{m}(\mathrm{C})$.
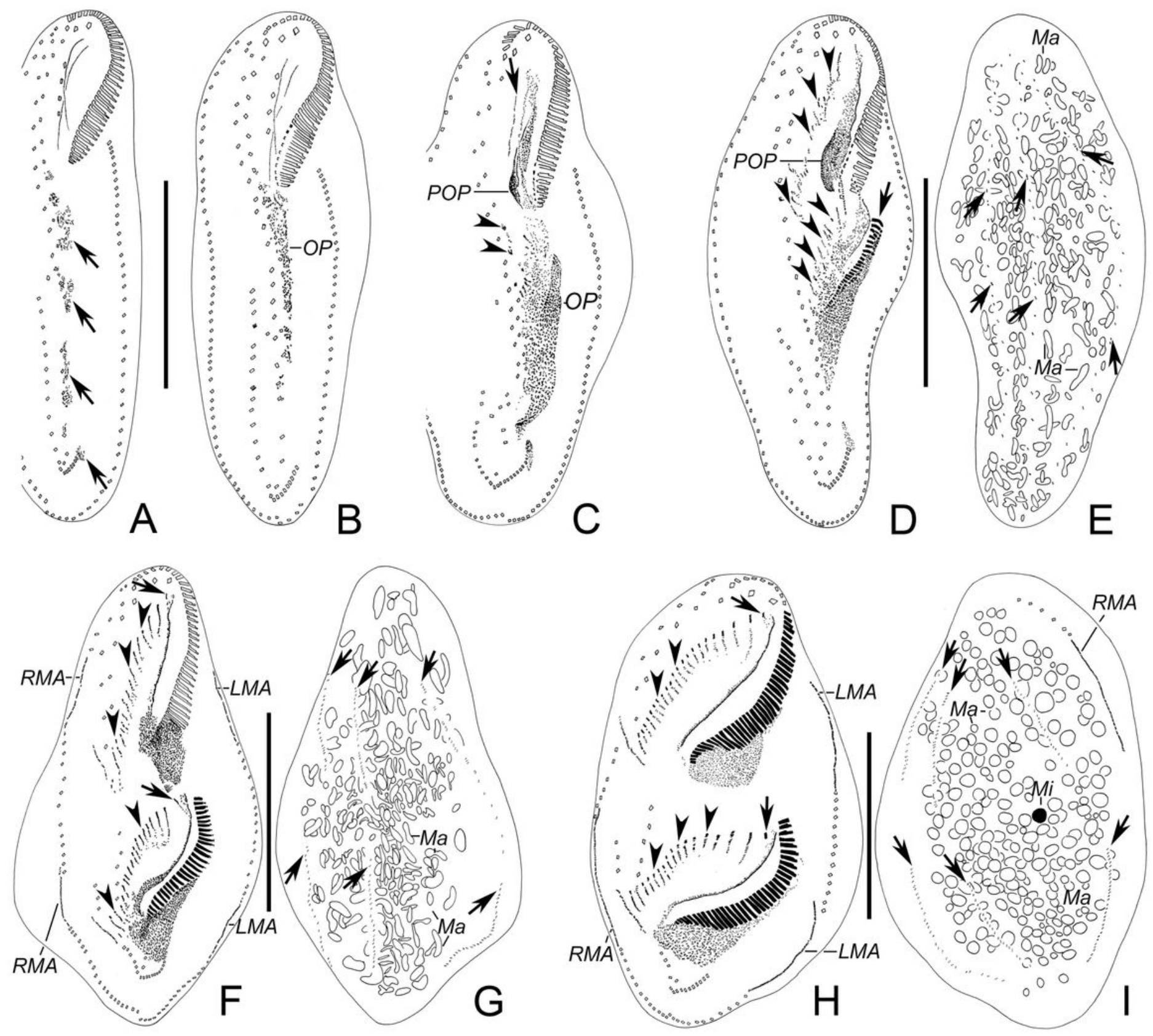

Figure 3

A-I. Morphogenesis of Bakuella (Pseudobakuella) guangdongica n. sp. after protargol preparation. (A, B) Ventral views of early divider, to show the oral primordium (arrows). (C) Ventral view, arrow marks the frontoventral-transverse cirral anlage originating with buccal cirri dedifferentiation, and arrowheads indicate that midventral cirri dedifferentiate and join the forming of the frontoventral-transverse cirral anlagen for the opisthe. (D, E) Ventral and dorsal view of the same specimen, arrow in $D$ points to the newly formed membranelles, arrowheads mark the frontoventral-transverse cirral anlagen, and arrows in E show the dorsal kineties anlagen. $(F-I)$ Ventral $(F, H)$ and dorsal $(G, I)$ views of early dividers, to show the development of the oral primordium and frontoventral-transverse cirral anlagen. Arrows in $\mathrm{F}, \mathrm{H}$ show 
the first frontal cirri separated from the undulating membranes anlagen, arrows in G, I mark the dorsal kineties anlagen, while arrowheads mark the frontoventral-transverse cirral anlagen. LMA, left marginal anlagen; Ma, macronuclear nodules; Mi, micronuclei; OP, oral primordium; POP, proter's oral primordium; RMA, right marginal anlagen. Scale bars $=80 \mu \mathrm{m}$.
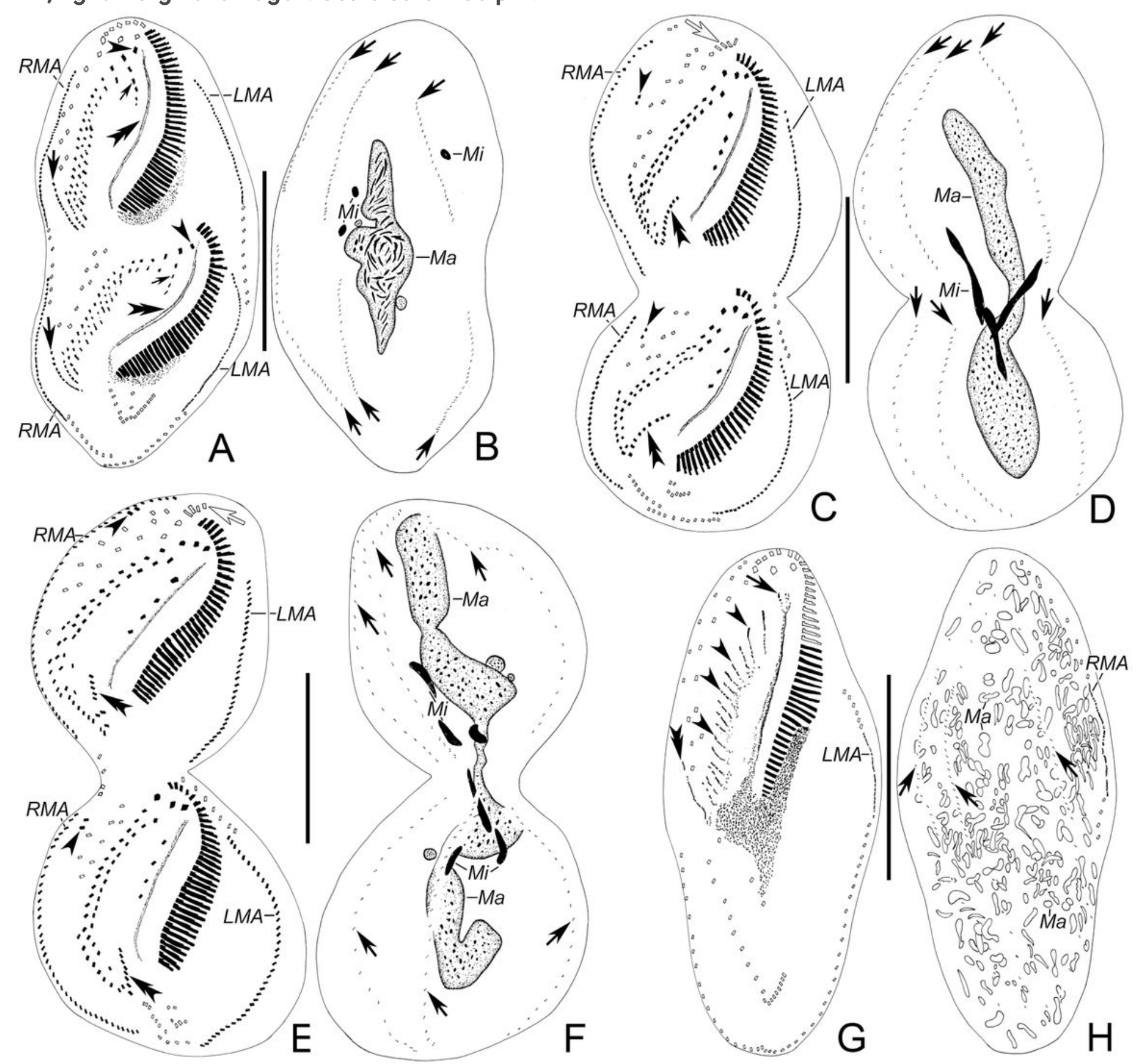

Figure 4

A-H. Middle and late stages of morphogenesis in Bakuella (Pseudobakuella) guangdongica $\mathbf{n}$. sp. after protargol staining. (A, B) Ventral and dorsal view of a mid-divider, arrows, arrowheads and small arrows in A show the rightmost frontoventral-transverse cirral anlagen, the left frontal and the buccal cirri, respectively. Double-arrowheads depict that the undulating membranes anlage split into new endoral and paroral in each filia product. Arrows in B mark the dorsal kineties anlagen. Note the macronuclear nodules 
fuse into a single mass. (C-F) Ventral and dorsal views of late dividers, arrows mark the dorsal kineties anlagen, arrowheads show the newly formed frontoterminal cirri, double-arrowheads point to the transverse cirri and hollow arrows depict the old membranelles. $(G, H)$ Ventral and dorsal view of a reorganiser, arrow in $\mathbf{G}$ shows that the first frontal cirrus separated from the undulating membranes anlage, arrows in $\mathrm{H}$ mark the dorsal kineties anlagen, arrowheads show the frontoventral-transverse cirral anlagen and double-arrowhead marks the rightmost frontoventral-transverse cirral anlage. LMA, left marginal anlagen; Ma, macronuclear nodules; Mi, micronuclei; RMA, right marginal anlagen. Scale bars = $60 \mu \mathrm{m}$. 


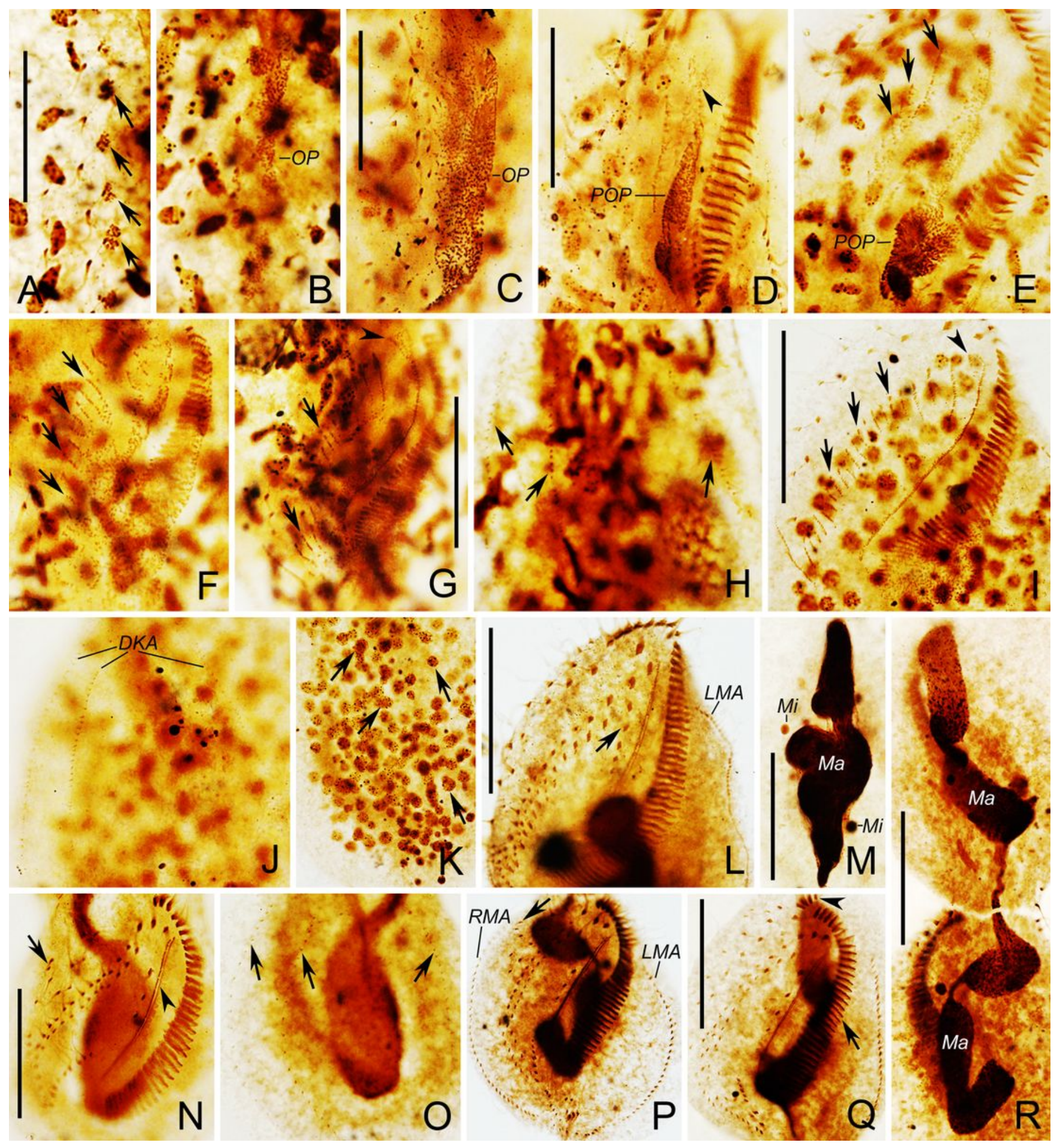

Figure 5

A-R. Photomicrographs of Bakuella (Pseudobakuella) guangdongica n. sp. during morphogenesis after protargol staining. (A-C) Ventral views of early dividers, to show the opisthe's oral primordium. (D, E) Ventral views, to show the proter's oral primordium, arrows show the frontoventral-transverse cirral anlagen. Note the parental paroral and endoral begin to dedifferentiate (arrowhead). (F, G, I) Ventral views, to mark the frontoventral-transverse cirral anlagen (arrows) and the leftmost frontal cirri separated from 
the undulating membranes anlagen (arrowheads). $(\mathrm{H}, \mathrm{J}, \mathrm{K})$ Dorsal views, to depict dorsal kineties anlagen ( $\mathrm{J}$, arrows in $\mathrm{H}$ ) and macronuclear nodules (arrows in $\mathrm{K}$ ). (L) Ventral view, to demonstrate the cirri newly formed. Arrow marks the buccal cirri. (M) Dorsal view, to show the macronuclear nodules and micronuclei. ( $N$ ) Ventral view, to show the frontoterminal cirri (arrow) and the separating paroral and endoral (arrowhead) in opisthe. $(\mathrm{O}, \mathrm{R})$ Dorsal views, to denote the dorsal kineties anlagen (arrows) and the macronuclear nodules. $(P, Q)$ Ventral views, arrow in $P$ demonstrates that the frontoterminal cirri migrate to their final positions and in Q marks the newly formed adoral zone of membranelles, while arrowhead depicts the old membranelles. DKA, dorsal kineties anlagen; LMA, left marginal anlagen; Ma, macronuclear nodules; Mi, micronuclei; OP, oral primordium; POP, proter's oral primordium; RMA, right marginal anlagen. Scale bars $=30 \mu \mathrm{m}$.

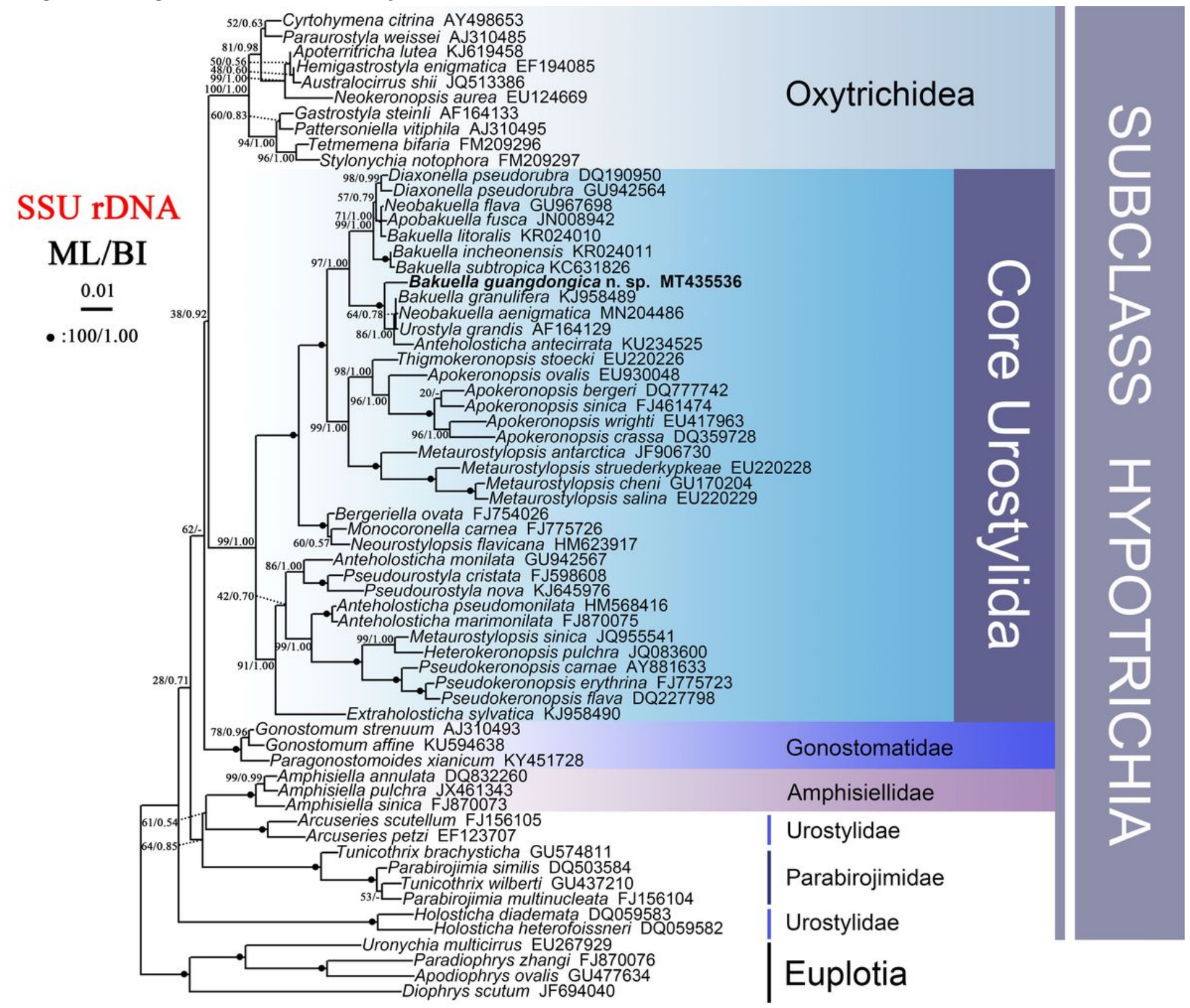

Figure 6 
Maximum likelihood (ML) tree based on the SSU rDNA sequence data. The newly sequenced Bakuella (Pseudobakuella) guangdongica $\mathrm{n}$. sp. is indicated in bold. Support values of nodes are for ML and Bayesian analysis $(\mathrm{BI})$, respectively. Fully supported branches are marked with solid circles at the nodes while "-" indicate the disagreement between ML and BI topologies. All branches are drawn to scale. The scale bar corresponds to 0.01 expected substitutions per site. 